\title{
Numerical Modeling and Experimental Validation in Orthogonal Machining of Aluminum Al 6061-T6 Alloy
}

\author{
SOHAIL AKRAM*, SHAFI UDDIN*, SYED WAQAR HAIDER KAZMI*, SYED HUSAIN IMRAN \\ JAFFERY*, MIAN AAMER JALIL **
}

RECEIVED ON 27.11.2018 ACCEPTED ON 19.02.2019

\begin{abstract}
Proper selection of cutting parameters, cutting tool material and geometry and machine tool selection is necessary for the production of high-quality products at reduced cost. Cutting forces produced during the machining process are important indicators of the cutting mechanism. The knowledge of the cutting forces during a machining operation helps to select a workpiece of a suitable strength in order to maintain dimensional tolerances by avoiding excessive distortions. Machining is one of the most common manufacturing operations today. A number of research works have been conducted in the past to quantify cutting forces experimentally and numerically during machining processes because theoretical calculations appeared to produce uncertain results due to complex workpiece and tool interaction and inherent complexity of machining process. The numerical analyses have been continuously improved for the prediction of the fundamental physical quantities. However, a general predictive model that can capture the real cutting operation is not available yet due to the presence of extremely complex phenomena associated with the actual cutting operation including tool-chip friction, adiabatic shear bands, free surfaces, high strains and strain rates and high temperatures etc. The objective of this research was to investigate the use of Johnson-Cook material model in simulating orthogonal cutting of Al 6061-T6 alloy. The idea in the current research was to develop a more economical solution to the existing dynamometers which are highly expensive. A cost-effective strain gauge based (mechanically decoupled, beam type static) dynamometer has been designed, developed and tested for finding the cutting forces during orthogonal machining operation which was not considered in the past research studies. Results of force variations measured experimentally through strain gauge based dynamometer as well as predicted numerically through simulation were compared with the published results during machining of Aluminum alloy Al 6061-T6 and found in good agreement.
\end{abstract}

Key Words: Cutting Forces, Orthogonal Machining, Finite Element Model, Dynamometer, Strain Gauge, Al 6061-T6 Alloys.

\section{INTRODUCTION}

I

$\mathrm{n}$ the machining process, a piece of raw material is machined into a desired final shape and size by a processes are used to achieve the desired shape, tolerances and surface finishes that are difficult to obtain controlled material-removal process [1]. Machining by other means. Optimization of the material removal

Authors E-Mail: (Sohail.Akram@smme.nust.edu.pk, shafi2841@yahoo.com, syedwaqarhaider_kazmi@yahoo.com, imran@smme.nust.edu.pk, aamerjalil74@gmail.com)

* School of Mechanical and Manufacturing Engineering, NUST, Islamabad, Pakistan.

** National Engineering and Scientific Commission, H13, Islamabad, Pakistan

This is an open access article published by Mehran University Research Journal of Engineering and Technology, Jamshoro under the CC by 4.0 International License. 
processes leads to increase dimensional accuracy, process efficiency and improvement in product quality. The machining process is influenced by many factors. Amongst these factors, the most important being cutting speed, feed rate, depth of cut, tool material and geometry of the tool. The objective of the metal cutting is to establish a predictive theory that would help us in predicting the cutting performance such as chip formation, variations in the cutting temperatures, cutting force variations, tool wear, surface finish and accuracy of the workpiece affected under different cutting parameters.

Extensive works have been carried out on milling process experimentally, theoretically and numerically in order to get optimized cutting parameters [2]. However, to study the shaping, milling or any other machining process by purely experimental approach has proven to be costly and time-consuming. It has been reported that the cost of the cutting tool alone is about $4 \%$ of the total cost of the machining process [3].The analysis of a machining process is a complex phenomenon due to the involvement of many process parameters. Finite Element simulation has helped researchers to predict different parameters like cutting force variations, temperature variations, and chip formation during the cutting process. These finite element simulations have helped to deepen the understanding of the cutting process and eliminating expensive experiments.In the majority of the researches, the simulations have been compared and validated with the experimental results [4]-10].

Metal cutting is a vast area of research and a considerable amount of studies have been done on finding the cutting forces through different types of dynamometers. Measurement of the cutting forces $(\mathrm{Fc})$ can be used as a diagnostic tool for the analysis and the optimization of the machining process. Moreover, the quality and costeffectiveness of the machined component and the tool life can be improved by investigating the results of the cutting forces.Many researchers have worked on the development of force dynamometer to measure the force variation during the cutting process.

Table 1 shows a brief summary of work done to develop dynamometer in the past. Totis et. al. [11] designed a plate dynamometer using a piezoelectric sensor for measurement of three components i.e. radial force (Fx), tangential force (Fy) and axial force (Fz) of the resultant forces. Force range was $>1000 \mathrm{~N}$ with a frequency band of $3000 \mathrm{~Hz}$. The drawback of this design was being for midrange applications and was used relatively with small cutters, high spindle speed and was limited to conventional or micromachining. Totis and Sortino [12] used a modular design which allowed the easy change of the cutting insert without altering the functions of the sensors and which can also measure the triaxial forces. Measured forces were in the range of 10-5000N. Yaldýz and Unsaçar [13] designed a base plate mounted on a lathe with bracket using piezoelectric quartz cells which worked as force transducers with three component of the forces, having forces in the range of $3500 \mathrm{~N}$. This was suitable for the measurement of static and dynamic cutting forces. Korkut [14] designed a tool shank using piezoelectric strain gauges with three component of forces which were limited to $2000 \mathrm{kgf}$. Although designed for milling operation but it could also be used for other machining processes like turning and drilling etc. Seker et. al. [15], Yaldýz and Unsaçar [16], Yaldýz et. al. [17] and Karabay [18], worked on the same design principal of the dynamometer during turning operation. They worked on octagonal ring using piezoelectric strain gauges to measure static and dynamic cutting forces with three force components and their force ranges up to $3500 \mathrm{~N}$ and bend frequency is not specified. Oraby and Hayhurst [19] designed a dynamometer by using bending beam type load cells for measurement of the three force components, the force range was $2000 \mathrm{~N}$ but their bend frequency was not specified. So the drawback of this strategy is that the cross sensitivity will be low when the cutting forces are not in an accurate location. 
Up till now, many attempts have been made to measure cutting forces in aluminum (Al 6061-T6) and titanium alloys (Ti-6Al-4V) of which the Xu et al. [20] found the feed force and cutting force while machining of aluminum alloy (Al 6061-T6). Although there was a wide range of gap between experimental and simulated data but the trend of cutting force and feed force were in good agreement with the experimental data. Sima and O“zel [21] also made an attempt to find out the cutting force and feed force in machining of Ti-6Al-4V by using uncoated carbide tool, Force dynamometer and high-speed data acquisition devices were used to measure the cutting forces.

The current research aims to develop a more economical solution to the existing dynamometers which are highly expensive [22-23] hence the idea to determine cutting forces $(\mathrm{Fc})$ by measuring specific cutting energy using the power meter [6] and numerical methods. In the present work, Fc (Cutting Forces) that act in the direction of the cutting speed (v) and are responsible for supplying the required energy for the orthogonal machining process were measured experimentally and numerically. The Fc were measured experimentally using strain-gauge based dynamometer developed in-house and also numerically by applying the J-C (Johnson-Cook) material model during orthogonal cutting of aluminum alloy (Al 6061T6). The experimental and predicted results obtained in the current research work were compared with the results available in the published literature.

TABLE 1. SUMMARY OF WORK DONE TO DEVELOP DYNAMOMETER IN THE PAST

\begin{tabular}{|c|c|c|c|c|c|}
\hline No. & Sensor Location & Sensor Description & Force Components & $\begin{array}{l}\text { Range } \\
(\mathrm{N})\end{array}$ & References \\
\hline 1. & $\begin{array}{l}\text { Plate dynamometer platform } \\
\text { (workpiece fixture) }\end{array}$ & $\begin{array}{c}\text { Piezoelectric triaxial force cells Kistler } \\
\text { type } 9016 \mathrm{~B} 4 \text { arranged in a novel } \\
\text { triangular configuration }\end{array}$ & $(\mathrm{Fx}, \mathrm{Fy}, \mathrm{Fz})$ & $>1000$ & $\begin{array}{l}\text { Totis et. al. } \\
\quad[11]\end{array}$ \\
\hline 2. & Tool shank & $\begin{array}{l}\text { Modular dynamometer which allows } \\
\text { easy exchange of inserts. }\end{array}$ & Triaxial & $10-5000 \mathrm{~N}$ & $\begin{array}{l}\text { Totis and Sortino } \\
{[12]}\end{array}$ \\
\hline 3. & $\begin{array}{l}\text { Octagonal shape } \\
\text { Strain rings }\end{array}$ & $\begin{array}{l}\text { A dynamometer that uses strain gauges } \\
\text { and piezo-electric accelerometer to } \\
\text { measure static and dynamic cutting } \\
\text { forces. Care has been taken to } \\
\text { maximize the sensitivity and to reduce } \\
\text { the cross-sensitivity. }\end{array}$ & $\begin{array}{l}\text { Three-force } \\
\text { component }\end{array}$ & $3500 \mathrm{~N}$ & $\begin{array}{c}\text { Yald?z and Unsaçar } \\
\text { [13] }\end{array}$ \\
\hline 4. & Elastic octagonal rings & $\begin{array}{l}\text { Milling dynamometer, in which strain } \\
\text { gauges were mounted on octagonal } \\
\text { rings manufactured in-house. }\end{array}$ & $\begin{array}{l}\text { Three-force } \\
\text { components }\end{array}$ & $1500-4500 \mathrm{~N}$ & $\begin{array}{c}\text { Korkut } \\
\text { [14] }\end{array}$ \\
\hline 5. & Tool holder & $\begin{array}{l}\text { Bending beam type load cells were } \\
\text { used in the design }\end{array}$ & $\begin{array}{l}\text { Three-force } \\
\text { components }\end{array}$ & 2002 & $\begin{array}{l}\text { Seker et. al. } \\
{[15]}\end{array}$ \\
\hline 6. & $\begin{array}{l}\text { Octagonal rings with mounted } \\
\text { strain gages }\end{array}$ & $\begin{array}{c}\text { Turning C-dynamometer using strain } \\
\text { gauges in conjunction with piezo- } \\
\text { electric Accelerometer }\end{array}$ & $\begin{array}{l}\text { Three-force } \\
\text { components }\end{array}$ & $3500 \mathrm{~N}$ & $\begin{array}{c}\text { Yald?z and Unsaçar } \\
{[16]}\end{array}$ \\
\hline 7. & $\begin{array}{l}\text { Octagonal rings with mounted } \\
\text { strain gages }\end{array}$ & $\begin{array}{l}\text { Milling Plate dynamometer, which uses } \\
\text { strain gauges along with piezo-electric } \\
\text { accelerometer attached on to flexible } \\
\text { octagonal rings }\end{array}$ & $\begin{array}{l}\text { Three-force } \\
\text { components }\end{array}$ & $5000 \mathrm{~N}$ & $\begin{array}{l}\text { Yald?z et. al. } \\
\qquad[17]\end{array}$ \\
\hline 8. & $\begin{array}{l}\text { Octagonal rings with mounted } \\
\text { strain gages. }\end{array}$ & $\begin{array}{c}\text { Octagonal rings mounted with strain } \\
\text { gauges to measure cutting forces } \\
\text { during drilling }\end{array}$ & $\begin{array}{l}\text { Three-force } \\
\text { components }\end{array}$ & $3500 \mathrm{~N}$ & $\begin{array}{c}\text { Karabay } \\
\quad[18]\end{array}$ \\
\hline 9. & $\begin{array}{c}\text { Fitted in the oval opening of a } \\
\text { Tool shank. }\end{array}$ & $\begin{array}{c}\text { Piezo-electric shank type } \\
\text { dynamometer, which can measure the } \\
\text { three components composed of a } \\
\text { piezoelectric quartz Force transducer } \\
\text { type YDS- III } 79\end{array}$ & $\begin{array}{l}\text { Three-force } \\
\text { components }\end{array}$ & $2000 \mathrm{kgf}$ & $\begin{array}{l}\text { Rizal et. al. } \\
\text { [22] }\end{array}$ \\
\hline
\end{tabular}

Mehran University Research Journal of Engineering \& Technology, Volume 39, No. 1, January, 2020 [p-ISSN: 0254-7821, e-ISSN: 2413-7219] 


\section{METHODOLOGY TO DEVELOP STRAIN-GUAGE BASED DYNAMOMETER}

\subsection{Shape Selection}

The aim of the present work is to design a structure that satisfies the following requirements.

- Should hold a tool shank firmly with the crosssection of $25 \times 25 \mathrm{~mm}$.

- $\quad$ The tool which can be adjusted for various sizes of workpieces.

- It should be able to be accommodated on the turret for various sizes of workpieces.

- Should be able to align elastic elements in the direction of desired cutting forces.

- Assembly and disassembly on and from the turret should be easy.

- Cabling of the data acquisition system can be accessed without any risk of damaging.

\subsection{Material Selection}

Dynamometer structure should be rigid enough to withstand machining forces and vibration with a good factor of safety for fatigue life. Stainless Steel of grade 304 has been selected as a material for tool holding as well as the elastic elements of the dynamometer. The properties of force sensing material are defined by its material and design. Here are several factors for selecting the material of the force sensing element, including environmental concerns, the magnitude of the force, mechanical integration, rigidity, high natural frequency and corrosion resistance. Stainless steel grade 304 was chosen in order to meet the desired specifications. The mechanical properties of SS 304 are listed in Table 2.

\subsection{Strength Analysis and Shape Optimization}

FE (Finite Element) based software ANSYS was used for the structural analysis. The Von Mises stress distribution is shown in Fig. 1. It was obtained by applying a load of $1000 \mathrm{~N}$ in cutting force direction and $1000 \mathrm{~N}$ load on the feed force arm separately. From the simulation, maximum stress for $1000 \mathrm{~N}$ was determined to be $52.24 \mathrm{MPa}$ while tensile yield strength of stainless steel 304 was $215 \mathrm{MPa}$. The factor of safety was considered to be " 4 ".

\section{$2.4 \quad$ Structure Optimization}

For structure optimization, the following Equations (1-3) [22] were used to select an appropriate cross-section of the elastic beams. For a beam subjected to a moment force, the maximum stress is defined by the term Flexural stress and is given by Equation (1).

Flexural Stress $=\frac{\mathrm{MC}}{1}$

Where,

$1=\frac{\mathrm{bt} 3}{12}$

And,

$\mathrm{c}=\frac{\mathrm{t}}{2}$

TABLE 2. MECHANICAL PROPERTIES OF SS-304

\begin{tabular}{|c|c|}
\hline Density & $8.00 \mathrm{~g} / \mathrm{cc}$ \\
\hline Hardness, Rockwell B & 70 \\
\hline Tensile Strength, Ultimate & $505 \mathrm{MPa}$ \\
\hline Tensile Strength, Yield & $215 \mathrm{MPa}$ \\
\hline Elongation at Break & $70 \%$ \\
\hline Modulus of Elasticity & $193 \mathrm{GPa}$ \\
\hline Poisson's Ratio & 0.29 \\
\hline Shear Modulus & $77.0 \mathrm{GPa}$ \\
\hline
\end{tabular}

Mehran University Research Journal of Engineering \& Technology, Volume 39, No. 1, January, 2020 [p-ISSN: 0254-7821, e-ISSN: 2413-7219] 
where ' $\mathrm{m}$ ' is the moment, ' $c$ ' is the distance from the neutral axis to the edge of the beam, ' $\mathrm{I}$ ' is the moment of inertia, ' $b$ ' is the width of the section of the cantilever beam (for designed structure, $b=8 \mathrm{~mm}$ ) and ' $\mathrm{t}$ ' is the thickness of the section of the cantilever beam (for designed structure, $\mathrm{t}=13 \mathrm{~mm})$.

Using the optimized values, the model of the strain gauge based dynamometer was designed and manufactured. The final model and the actual strain gauge based dynamometer while going through a wire-cut EDM (Electric Discharge Machining) process are shown in
Fig. 2(a-b), respectively. The total cost of manufacturing the current strain gauge based dynamometer was approximately $\$ 1000$ which was much lower compared to cost of the piezoelectric dynamometers [22-23].

In Fig. 2(a), both $\mathrm{A}$ and $\mathrm{C}$ are cutting force measuring arms whereas, both B and D are feed force measuring arms. A metallic foil type linear strain gauge having the specification ECH-350-6AA-(16)-O-SP was installed on the arms, as shown in Fig. 3. Both arms A and B were each installed with four strain gauges whereas both arms $C$ and $D$ were installed with two strain gauges each on their faces.

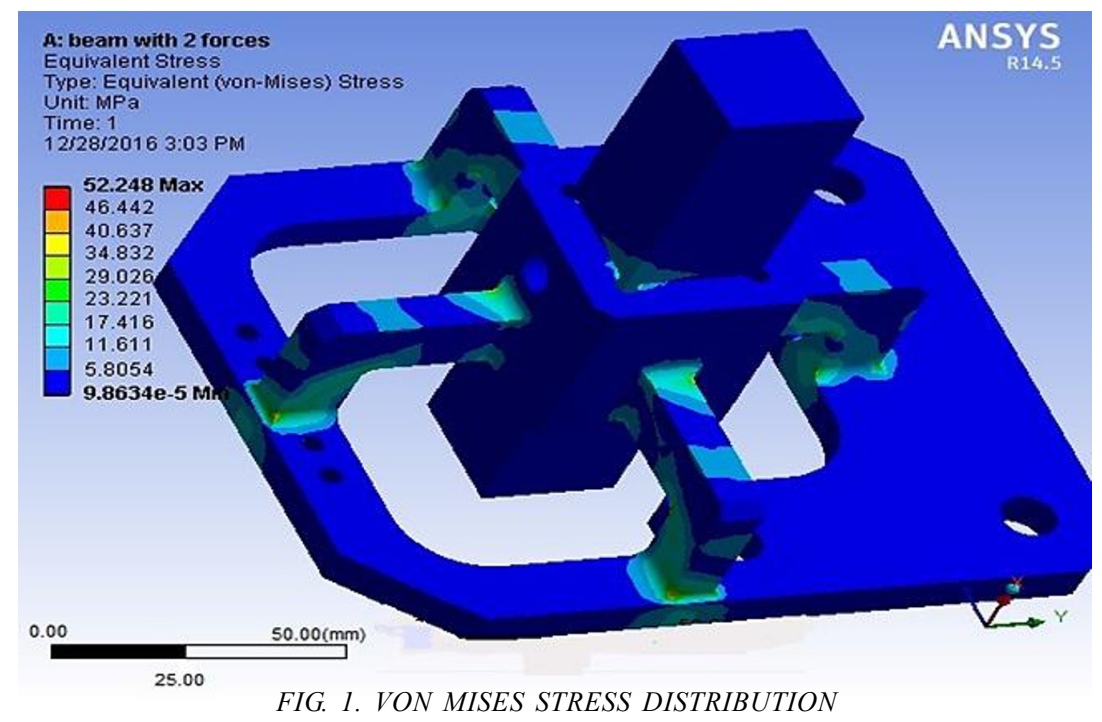

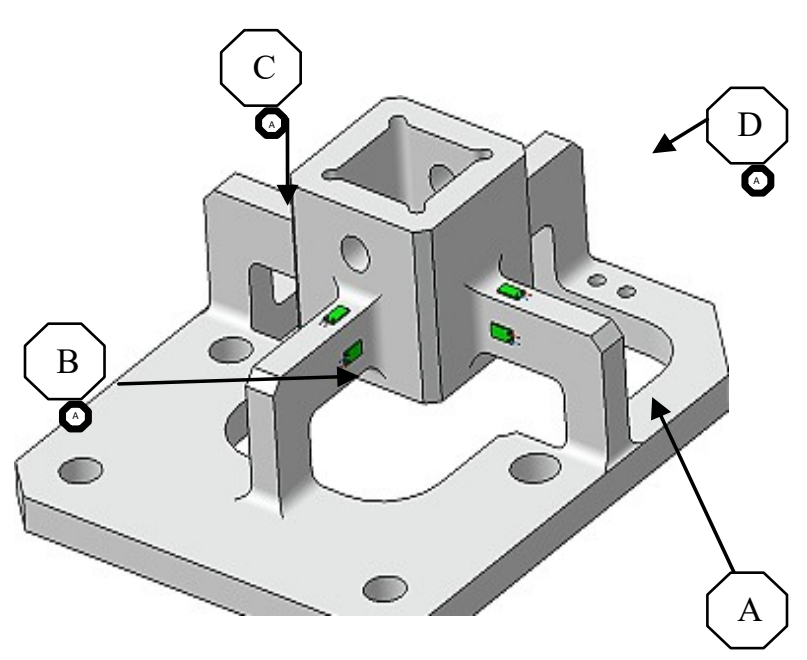

FIG. 2(A).THE FINAL MODEL

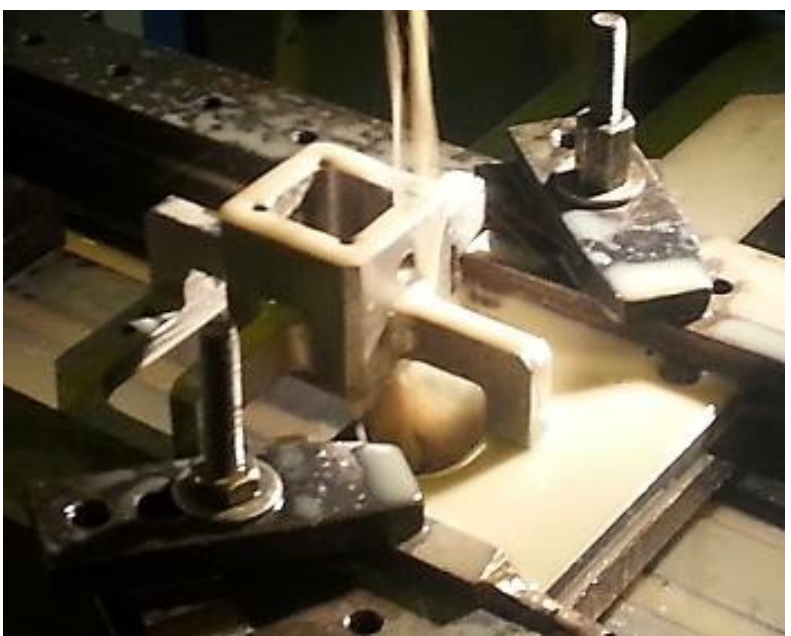

FIG.2(B) THE ACTUAL STRAIN GAUGE BASED DYNAMOMETER WHILE GOING THROUGH AN EDM PROCESS

Mehran University Research Journal of Engineering \& Technology, Volume 39, No. 1, January, 2020 [p-ISSN: 0254-7821, e-ISSN: 2413-7219] 


\subsection{Calibration of Dynamometer}

Before conducting experimental work, the strain gauge based dynamometer was calibrated. The calibration setup is shown in Fig.4. The calibration was done in order to find the relationship between microvolt and force. For this reason, dynamometer was calibrated by applying different loads. A plot between weight (force) and microvolt was obtained as shown in Figs. 5-6. Linear trend was observed between load and microvolt. For cutting force, top and bottom arms were set in the full bridge configuration, as shown in Fig. 7(a-b). Furthermore, this full bridge strain gauge configuration was connected to a personal computer (PC) through DAQ (Data Acquisition System), NI DAQ-9219 and the data was obtained through Lab view software. LabVIEW [11] is a system engineering software for the application that requires test, measurement and control with rapid access to hardware and data insights. The dynamometer was calibrated by placing dead weights on arms (feed force arm and cutting force arm) through a hanger and it was concluded that:

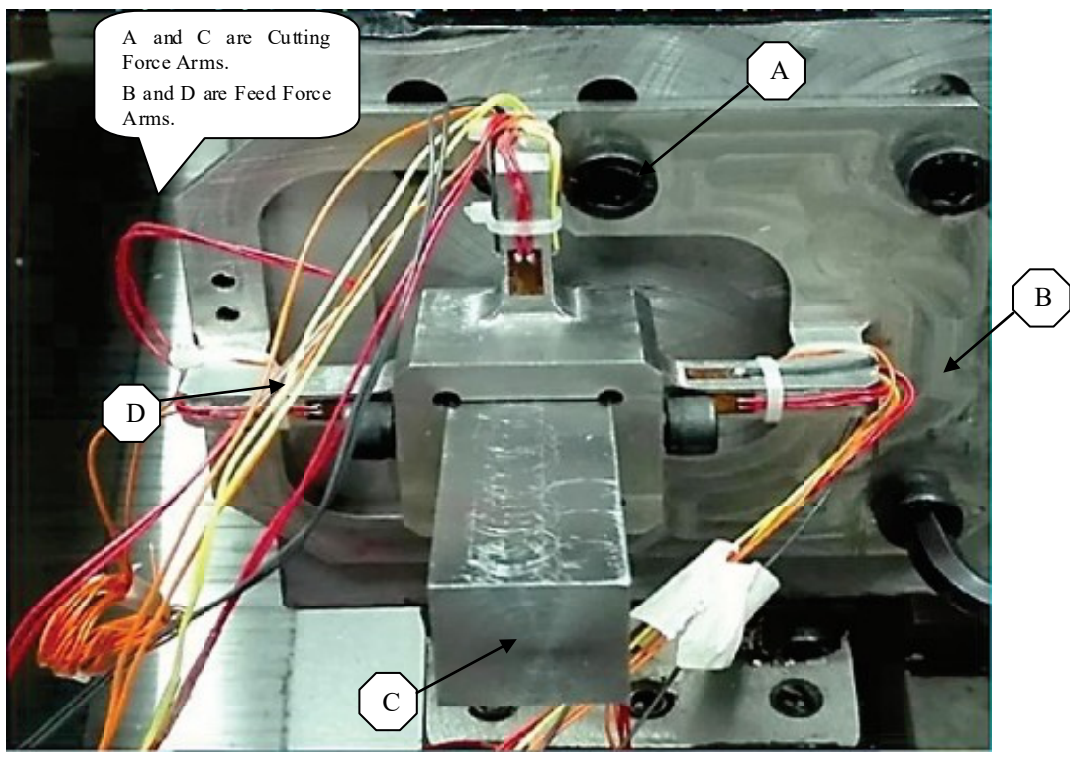

FIG. 3. FABRICATED DYNAMOMETER WITH INSTALLED STRAIN GAUGES

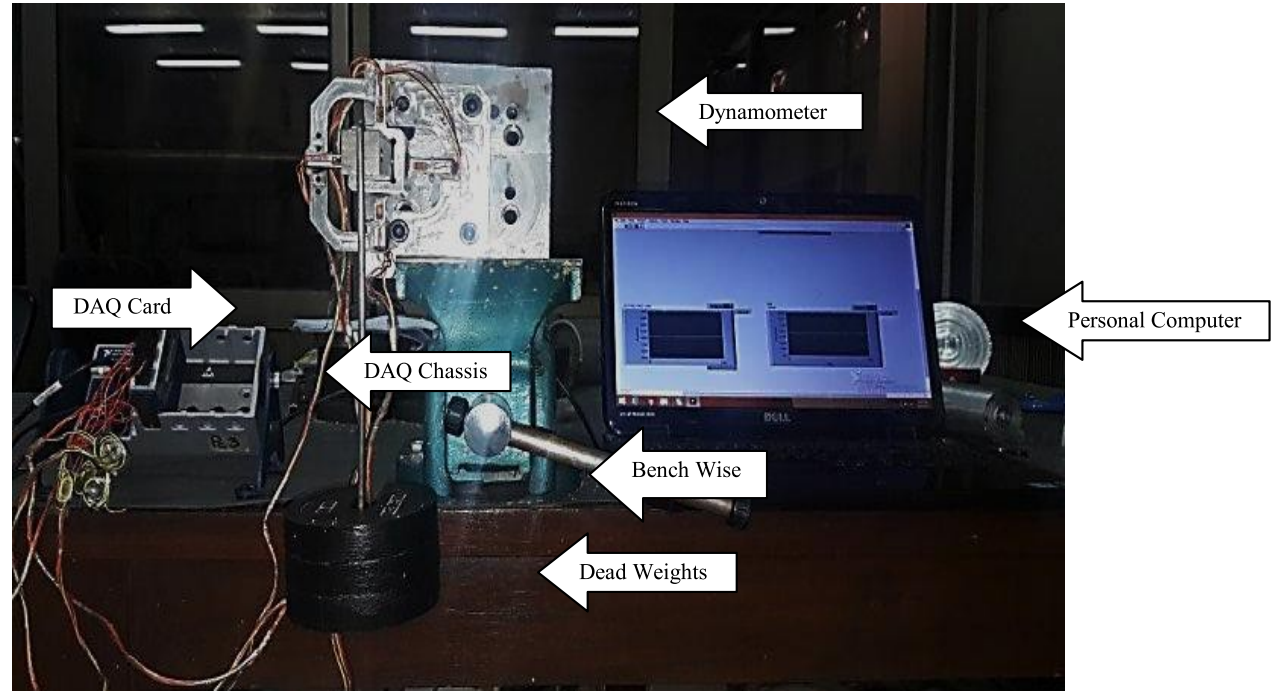

FIG. 4. CALIBRATION SETUP

Mehran University Research Journal of Engineering \& Technology, Volume 39, No. 1, January, 2020 [p-ISSN: 0254-7821, e-ISSN: 2413-7219] 
For Feed Arm, $1 \mu \mathrm{V}=9.81$ Newton

For the Cutting Arm, $1 \mu \mathrm{V}=35.714$ Newton

\section{EXPERIMENTATION}

The experimental work was carried out in SMME (School of Mechanical and Manufacturing Engineering) Lab, National University of Sciences \& Technology, Islamabad, Pakistan.In the present work, a CNC Lathe (ML-300) was used for carrying out the machining operation. The raw material was a tube of $198 \mathrm{~mm}$ in diameter. The machining parameters that were used during experimentation are shown in Table 3.

DAQ (Data Acquisition) system requirements are as given.

\section{- $\quad$ (DAQ Card (NI DAQ-9219)}

- DAQ Chassis (NI cDAQ-9174)

- $\quad$ Power Cables Data Cable

- Laptop/PC Lab View Software installed on Laptop/PC DAQ Drivers

- Lab View Device drivers

- $\quad$ Flexible Teflon wires connected to strain gauges.

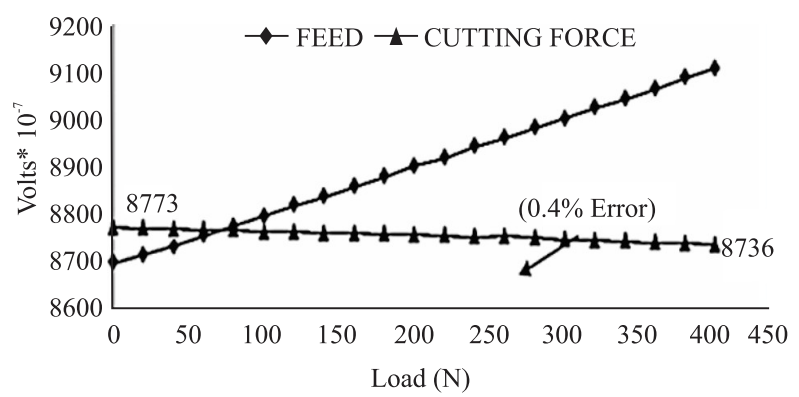

FIG. 5. FEED FORCE ARM CALIBRATION

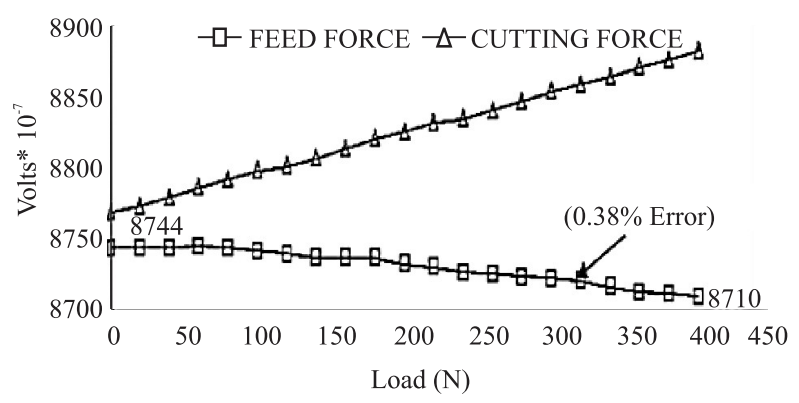

FIG. 6. CUTTING FORCE ARM CALIBRATION
NI DAQ-9219 has got 4-channels with 24-Bit universal Analogue Input Module. It is used for multipurpose testing in any Compact DAQ chassis. Several signals can be measured from sensors like strain gauge and RTD. Out of 4 channels, any channel can be selected for measurement purposes. The machining was carried out using the cutting conditions as discussed earlier and the DAQ system was us ed for the measurement of cutting forces.

\section{FULL BRDCE CONFGCURAOX}

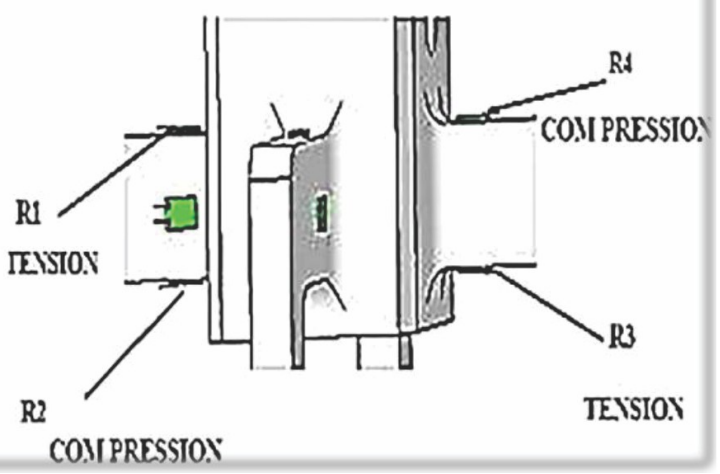

FIG. 7(A).SIDE VIEW OF FULL BRIDGE CONFIGURATION

\section{FILL BRWGE CONEIGLRATION \\ R2}

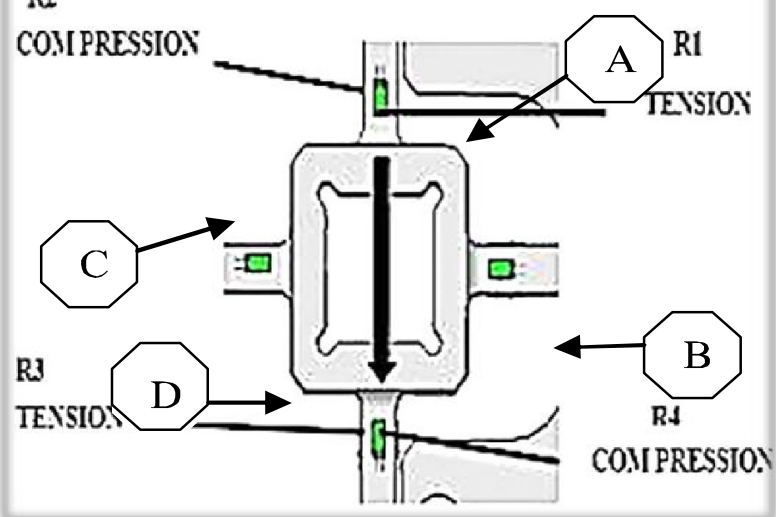

FIG 7(B).TOP VIEW OF FULL BRIDGE CONFIGURATION

TABLE 3. MACHINING PARAMETERS.

\begin{tabular}{|c|c|}
\hline Parameter & Value \\
\hline Cutting speed $\mathrm{m} / \mathrm{min}$ & $100,300,700,1300$ \\
\hline Feed, $\mathrm{mm} / \mathrm{rev}$ & $0.06,0.09,0.12$ \\
\hline Depth of cut, $\mathrm{mm}$ & 4.1 \\
\hline
\end{tabular}




\section{FINITE ELEMENT FORMULATION}

In the present research, experimental results, as well as the cutting force results obtained from the available literature, were validated using a FEM (Finite Element Model). For this purpose, a coupled thermo-mechanical model developed in the FE analysis software ABAQUS/ Explicit [24]was used. Material plasticity model, damage model and the friction model are important aspects of the FEM; the following sections elaborate them in detail.

\subsection{Material Model}

Much of the difficulty to accurately model a machining process arises from the large strains, strain rates and adiabatic heat produced which, in turn, cause an increase in temperature with resulting changes in material microstructure, material properties and deformation mechanisms [6], [25]. Proper flow stress models are required in FE analysis to represent material behavior, which is a function of strain, strain rate and thermal deformation conditions. Oxley [5], Johnson-Cook [26-27] and Zerilli-Armstrong models [5,28-29] are the commonly used laws applied in the simulation of the machining process. Johnson-Cook material model $[7,30]$ combines the different effects of strains, strain rate, and temperature. It is most widely used for the simulation of the machining processdue to its simple form of the constitutive equation, availability of material constants and cumulative damage law to asses failure[25]. J-C constitutive modeling is a mathematical description of how a material behaves under various cutting conditions and to a great extent can predict the material behavior in static and dynamic conditions [31]. The $\mathrm{J}-\mathrm{C}$ constitutive plasticity model is a purely empirical model and is suited to model high strain rate deformation of metals. J-C [26-27] conducted a number of experiments by varying the temperatures and over a wide range of strain-rate using the torsion and dynamic Hopkinson test bar equipment.

$\mathrm{J}-\mathrm{C}$ constitutive modeling is generally used in adiabatic transient dynamic analysis and is suitable for problems where the strain rate is in the range of 102-106 sec-1[3233]. Johnson-Cook plasticity model is given by Equation (4) $[6,8,26-27,31,33-39]$

$$
\sigma=\left(\mathrm{A}+\mathrm{B} \varepsilon^{\mathrm{n}}\right)\left(1+\mathrm{Cln} \frac{\dot{\varepsilon}}{\dot{\varepsilon}_{\mathrm{O}}}\right)\left(1-\left(\frac{\mathrm{T}-\mathrm{T}_{\text {room }}}{\mathrm{T}_{\text {melt }}-\mathrm{T}_{\text {room }}}\right)^{\mathrm{m}}\right)
$$

The J-C plasticity model is a function of strain, strain rate and temperature. The expression in the first set of brackets shows the strain effect, the second set of bracket shows the effect of strain-rate on yield-strength of the material whereas the last expression in the third bracket shows the thermal softening effect on the yield strength. It should be noted that yield stress drops to zero as the temperature reaches to the melting point. The constant values for $\mathrm{Al} 6061-\mathrm{T} 6$ alloy that is used in the finite element analysis are given in Table 4 and the corresponding mechanical properties are given in Table 5.

TABLE 4. JOHNSON-COOKOK MATERIAL MODEL CONSTANTS FOR AL 60616 -T ALLOY [6,25,40]

\begin{tabular}{|c|c|c|c|c|c|}
\hline Material & $\mathrm{A}(\mathrm{MPa})$ & $\mathrm{B}(\mathrm{MPa})$ & $\mathrm{C}$ & $\mathrm{n}$ & $\mathrm{m}$ \\
\hline $\mathrm{Al} 6061-\mathrm{T} 6$ & 324 & 114 & 0.002 & 0.42 & 1.34 \\
\hline
\end{tabular}

TABLE 5. RELEVANT MECHANICAL PROPERTIES OF AL 6061-T6 IN COMPARISON WITH OTHER ALLOYS OF RESEARCH INTEREST [6,41-42]

\begin{tabular}{|c|c|c|c|c|c|}
\hline \multirow{2}{*}{ Property } & \multicolumn{5}{|c|}{ Material } \\
\cline { 2 - 6 } & $\mathrm{Al} 6061-\mathrm{T} 6$ & $\mathrm{Al} 7075-\mathrm{T} 6$ & Ti-6Al-4V & Inconel 718 & AISI 4140 \\
\hline Density (g/cm3) & 2.7 & 2.81 & 4.43 & 8.22 & 7.85 \\
\hline Ultimate Tensile Strength (MPa) & 310 & 572 & 950 & 1350 & 1590 \\
\hline Yield Strength (MPa) & 275 & 503 & 880 & 1170 & 1460 \\
\hline Young's Modulus (GPa) & 69 & 71.7 & 113.8 & 200 & 207 \\
\hline Thermal Conductivity (W/m.K) & 167 & 130 & 6.7 & 11.4 & $33.1 \sim 42.7$ \\
\hline
\end{tabular}

Mehran University Research Journal of Engineering \& Technology, Volume 39, No. 1, January, 2020 [p-ISSN: 0254-7821, e-ISSN: 2413-7219] 


\subsection{Damage Model}

The J-C damage model is suitable where materials deform with high strain-rates [43]. The equivalent plastic strain is obtained at element integration points and failure is assumed to occur when the damage parameter exceeds one. When stress and deformation states in a small region ahead of tooltip satisfy damage initiation criteria, material starts to deform producing chips. J-C damage model is given by Equation(5) [26-27,39].

$$
\mathrm{D}=\sum\left(\frac{\Delta \bar{\varepsilon}}{\bar{\varepsilon}_{\mathrm{f}}}\right)
$$

Where, equivalent plastic strain, $\bar{\varepsilon}_{\mathrm{f}}$ is given by Equation (6) $[6,27,33,35]$ :

$\bar{\varepsilon}_{\mathrm{f}}=\left[\mathrm{D}_{1}+\mathrm{D}_{2} \exp \left(\mathrm{D}_{2} \frac{\mathrm{P}}{\bar{\sigma}}\right)\right]\left[1+\mathrm{D}_{2} \ln \left(\frac{\dot{\bar{\varepsilon}}}{\dot{\bar{\varepsilon}_{\mathrm{O}}}}\right)\right] \times\left[1+\mathrm{D}_{5}\left(\frac{\mathrm{T}-\mathrm{T}_{\text {room }}}{\mathrm{T}_{\text {melt }}-\mathrm{T}_{\text {room }}}\right)\right]$

The three terms in the above equation represent pressure dependency, strain-rate effect and the thermal effect, respectively. The values of five damage constants, D1-5 for Al 6061-T6 alloy is given in Table 6.

\subsection{Friction Model}

Friction occurs between rake face and the chip. It is one of the most complex phenomena in metal cutting operation and affects the variation in the cutting force, surface finish, tool wear and chip morphology etc. [45]. Friction can be generally considered as the tangential force generated between the two surfaces. In the current research work, the most simple friction model i.e. Columb's friction model is used. The present work assumes a constant value of the coefficient of friction as 0.25 [6,46-47]

\subsection{Modelling, Boundary Conditions and Loading}

Since the temperature generated during the machining operation significantly affect many parameters including chip morphology, cutting forces, residual stresses [4850] and tool wear [51-53] it is important to develop a model that can capture the temperature effects. Both the workpiece and tool with 0 o rake angleand 70 clearance angle has been kept deformable during the simulation of orthogonal machining. Fig. 8 shows meshing of workpiece and tool material.

TABLE 6. JOHNSON-COOK DAMAGE MODEL CONSTANTS.[6], [40], [44]

\begin{tabular}{|c|c|c|c|c|c|c|c|}
\hline Material & $\begin{array}{c}\text { Initial Failure } \\
\text { Strain, } \\
\mathrm{D}_{1}\end{array}$ & $\begin{array}{c}\text { Exponential } \\
\text { Factor, } \\
\mathrm{D}_{2}\end{array}$ & $\begin{array}{c}\text { Triaxiality } \\
\text { Factor, } \\
\mathrm{D}_{3}\end{array}$ & $\begin{array}{c}\text { Strain Rate } \\
\text { Factor, } \\
\mathrm{D}_{4}\end{array}$ & $\begin{array}{c}\text { Temperature } \\
\text { Factor, } \\
\mathrm{D}_{5}\end{array}$ & Troom & Tmelt \\
\hline $\mathrm{Al} 6061-\mathrm{T} 6$ & -0.77 & 1.45 & -0.47 & 0.0 & 1.6 & $20 ? \mathrm{C}$ & $650 ? \mathrm{C}$ \\
\hline
\end{tabular}

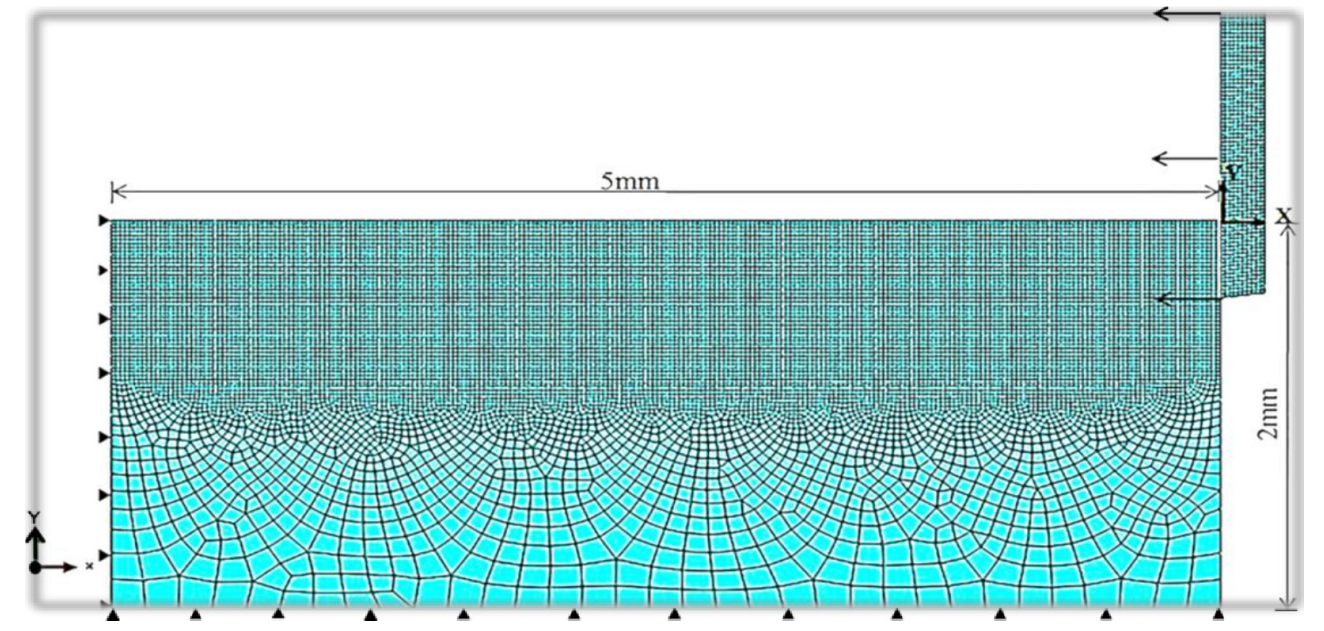

FIG. 8. FINITE ELEMENT MESHING AND BOUNDARY CONDITIONS SHOWING FIXED WORKPIECE AND TOOL VELOCITY GIVEN ALONG X-AXIS [6].

Mehran University Research Journal of Engineering \& Technology, Volume 39, No. 1, January, 2020 [p-ISSN: 0254-7821, e-ISSN: 2413-7219] 
Choice of the element is an important criterion to obtain better predicted of results. Performance of elements with low order shape functions is poor, however, they are usually preferred due to their inherent simplicity especially in cutting simulations where many complicated processes may be occurring simultaneously [54]. As Fig. 8, show the region of the workpiece above the datum line was meshed with a fine mesh to accurately capture the expected failure of the material in that region. 17649 Coupled Temperature-Displacement linear plane strain, quadrilateral elements with the reduced integration of type CPE4RT and the hourglass control effect were used in the workpiece region above the datum line. Coupled thermo-mechanical CPE4RT elements account for temperature-dependent material properties whereas hourglass control is suitable for high element deformation. Hourglass control is required when reduced integration with first-order (linear) elements is used [24]. A Quaddominated free meshing technique with advancing front algorithm was used for the meshing of workpiece and tool material. A mesh convergence study was performed for the machined zone and the best results were found by keeping the approximate element size of the fine mesh as $0.015 \mathrm{~mm}$. The rest of the workpiece material below the datum line was meshed with a relatively coarse mesh using 6174 Coupled Temperature-Displacement linear plane strain elements of type CPE4RT and 90 linear triangular elements of CPE3T type elements. This mesh scheme helps to minimize the total number of elements, thereby reducing the computational time and cost. The details about the element properties are given in Abaqus Analysis User's Guide [43].

\subsection{Cutting Conditions for Modeling}

Simulations for the 12 different cutting conditions were carried out to validate experimental and published results. The length of the workpiece material was set to be $5 \mathrm{~mm}$ whereas; the thickness was kept at $2 \mathrm{~mm}$. The workpiece material was constrained both in $x-y$ directions at the bottom of the workpiece whereas, the tool was given prescribed velocity on in $\mathrm{x}$-direction as shown in Fig. 8.

Cutting force, Fc generated for different cutting speeds and feed rates were determined by keeping the depth of cut, ap and tool geometry constant. These forces were then compared with the published and experimental results of the current research work using a strain-gauge based dynamometer in order to validate the current Finite Element model.

\section{RESULTS AND DISCUSSION}

Figs. 9-12 shows an average value of the predicted cutting force, Fc in the stable region obtained through Abaqus/ Explicit at the cutting condition of $\mathrm{v}=1300 \mathrm{~m} / \mathrm{min}$ and $\mathrm{f}=$ $0.12 \mathrm{~mm} / \mathrm{rev}$

Little variation was observed with increasing cutting speed both in experimental and simulated cutting force, $\mathrm{Fc}$ at a lower feed rate of $0.06 \mathrm{~mm} / \mathrm{rev}$ whereas, increasing feed rate from $0.06-0.12 \mathrm{~mm} / \mathrm{rev}$ significantly affected the cutting forces at all cutting speeds. In the first deformation zone, cutting speed can cause the strain and strain rate strengthening as well as thermal softening of the workpiece material [20]. The shear yield stress of the workpiece material increased with the increase of cutting speed because of stronger strengthening effect compared to softening effect leading to an increase of the cutting force. Furthermore, the shear angle was increased by increasing cutting speed leading to the decreased shear slip plane area and thus cutting force. However, the increased effect of the shear yield stress was weaker than the decreased effect of the shear plane area with the increase of cutting speed, resulting in a decrease of cutting force. The cutting force had a downward trend with the cutting speed although it could be affected by other minor factors.

Mehran University Research Journal of Engineering \& Technology, Volume 39, No. 1, January, 2020 [p-ISSN: 0254-7821, e-ISSN: 2413-7219] 


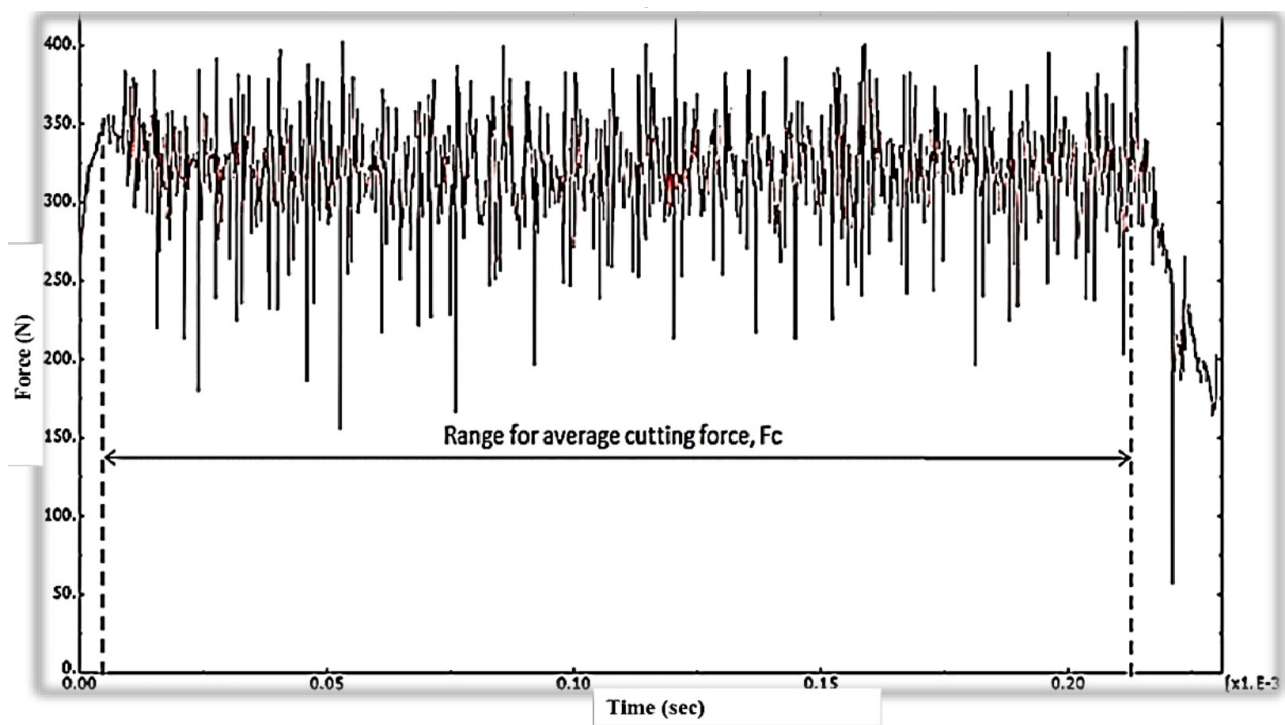

FIG. 9. CUTTING FORCE, FC AT V $=1300 \mathrm{M} / \mathrm{MIN} A N D F=0.12 \mathrm{MM} / \mathrm{REV}$

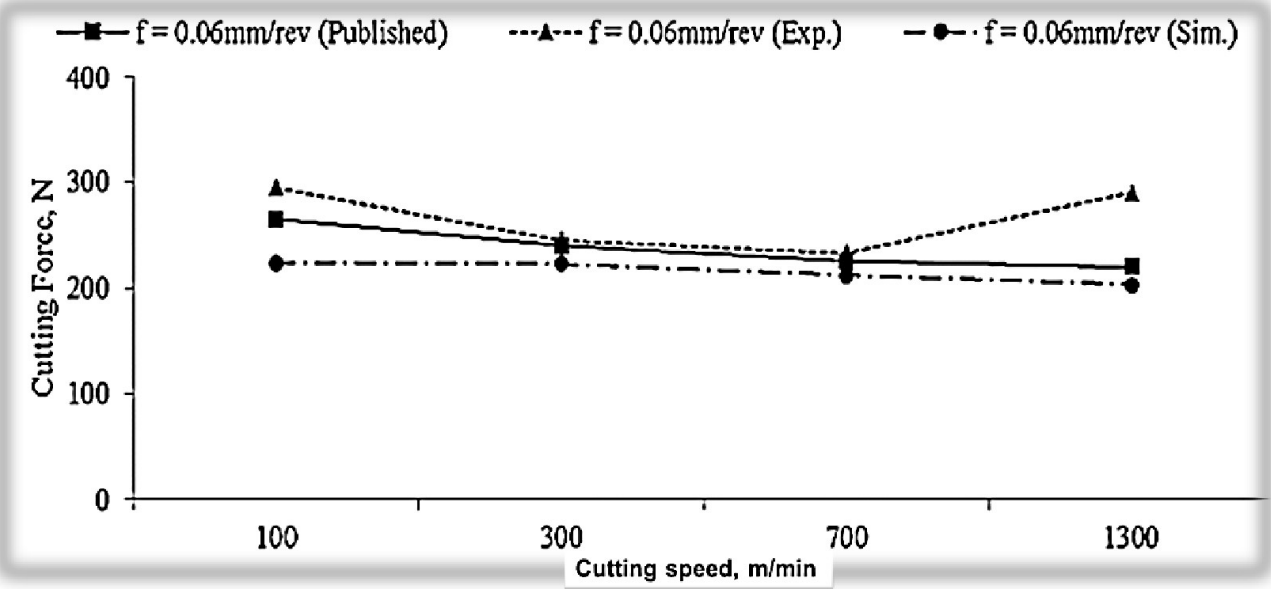

FIGURE 10. COMPARISON OF EXPERIMENTAL AND SIMULATED CUTTING FORCE, FC WITH THE PUBLISHED RESULTS AT THE FEED RATE, F $=0.06 \mathrm{MM} / \mathrm{REV}$

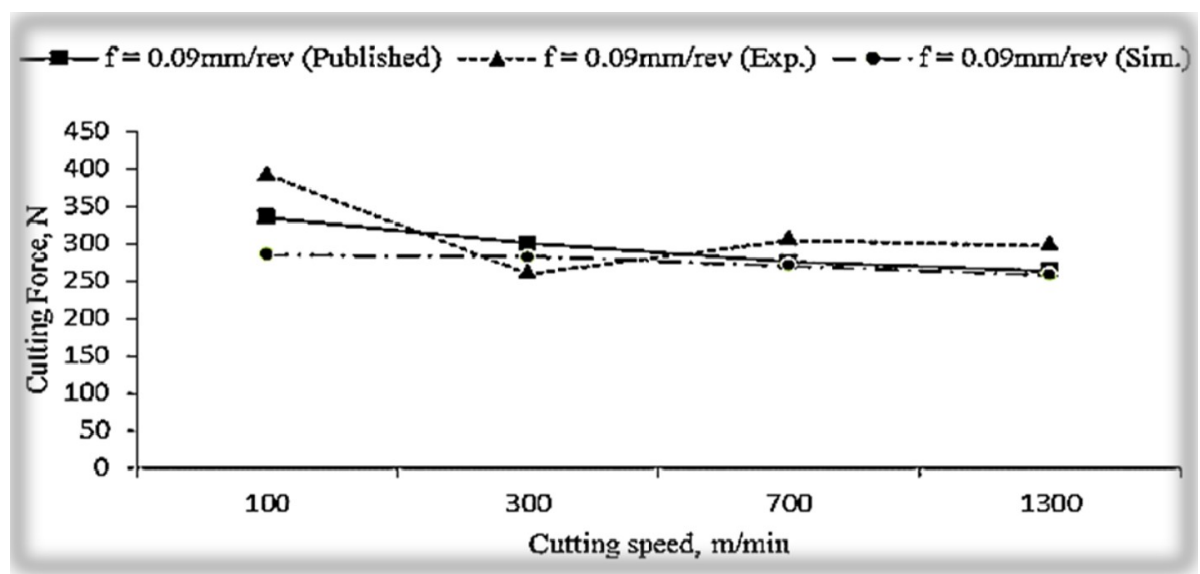

FIGURE 11. COMPARISON OF EXPERIMENTAL AND SIMULATED CUTTING FORCE, FC WITH THE PUBLISHED RESULTS AT THE FEED RATE, $F=0.09 M M / R E V$

Mehran University Research Journal of Engineering \& Technology, Volume 39, No. 1, January, 2020 [p-ISSN: 0254-7821, e-ISSN: 2413-7219] 


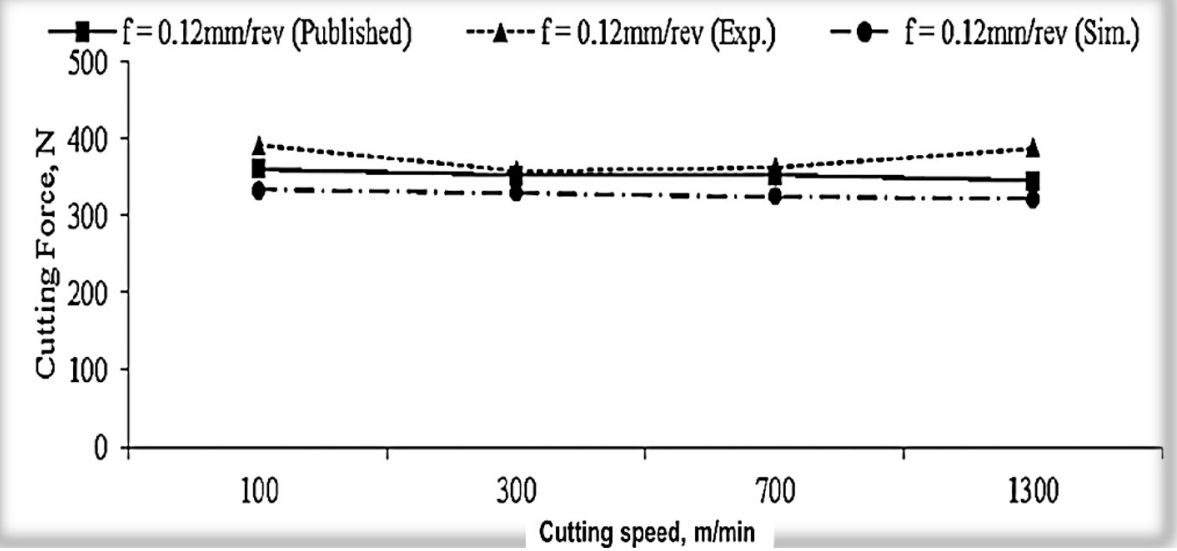

FIGURE 12. COMPARISON OF EXPERIMENTAL AND SIMULATED CUTTING FORCE, FC WITH THE PUBLISHED RESULTS AT THE FEED RATE, $F=0.12 M M / R E V$

\section{CONCLUSIONS}

The present paper puts forward the importance of designing, development and testing of a cost-effective strain gauge based dynamometer and exploring JohnsonCook material model used in coupled temperaturedisplacement module of Abaqus/Explicit software, to study cutting forces under different cutting conditions. The coupled thermo-mechanical model was developed and experimentally validated. The results of cutting forces obtained through simulation and experimentation were compared with the published results during machining of Al 6061-T6 alloy. Johnson-Cook constitutive equation with material constants obtained from the literature were implemented in Abaqus/Explicit software and the results were compared with the experimental work of the current research as well as the published experimental results. The good agreement obtained from strain gauge based dynamometer and numerical analysis with the published results of cutting forces shows that the proposed strain gauge based dynamometer and FEM model appear to be suitable for studying the machining of Al 6061-T6 alloy and also capable of predicting cutting forces with adequate accuracy.

\section{ACKNOWLEDGMENT}

This research is funded by the Higher Education Commission, Islamabad, Pakistan, under the indigenous 5000 Ph.D. Fellowship Programme, Batch-VII (Eg7-046). The authors also acknowledge the support and required resources provided by National University of Sciences \& Technology, Islamabad, Pakistan for performing this research work.

\section{REFERENCES}

[1] Kalpakjian, S. and Schmid, S. R., "Manufacturing Processes for Engineering Materials-5th Edition." Delhi: Pearson Education, Limited, 2011.

[2] Masmiati, N., Sarhan, A. A. D., Hassan, M. A. N., and Hamdi, M., "Optimization of Cutting Conditions for Minimum Residual Stress, Cutting Force and Surface Roughness in End Milling of S50C Medium Carbon Steel," Measurement: Journal of the International Measurement Confederation, Volume 86, pp. 253-265, 2016.

[3] Masood, I., Jahanzaib, M., and Wasim, A., "Sustainability Assessment for Dry, Conventional and Cryogenic Machining in Face Milling of Ti-6Al-4V," Mehran University Research Journal Of Engineering \& Technology, Volume 36, No. 2, pp. 309-320, 2017. 
[4] Ulutan, D., Lazoglu, I., and Dinc, C., "Three-Dimensional Temperature Predictions in Machining Processes Using Finite Difference Method," Journal of Materials Processing Technology, Volume 209, No. 2, pp. 1111-1121, 2009.

O?zel, T. and Zeren, E., "A Methodology to Determine Work Material Flow Stress and Tool-Chip Interfacial Friction Properties by Using Analysis of Machining," Journal of Manufacturing Science and Engineering, Volume 128, No. 1, pp. 119-129, 2006.

[6]

Akram, S., Jaffery, S. H. I., Khan, M., Fahad, M., Mubashar, A., and Ali, L., "Numerical and Experimental Investigation of Johnson-Cook Material Models for Aluminum (Al 6061-T6) Alloy Using Orthogonal Machining Approach," Advances in Mechanical Engineering, Volume 10, No. 9, pp. 1-14, Sep. 2018.

Daoud, M., Chatelain, J.-F., and Bouzid, H., "On the Effect of Johnson Cook Material Constants to Simulate A12024-T3 Machining Using Finite Element Modeling," ASME International Mechanical Engineering Congress and Exposition, Proceedings (IMECE), Volume 81, No. November, pp. 1987-1997, 2015.

Daoud, M., Jomaa, W., Chatelain, J. F., and Bouzid, A., "A Machining-Based Methodology to Identify Material Constitutive Law for Finite Element Simulation," International Journal of Advanced Manufacturing Technology, Volume 77, No. 9-12, pp. 2019-2033, 2015.

[9] Akbari, M., Buhl, S., Leinenbach, C., and Wegener, K., "A New Value for Johnson Cook Damage Limit Criterion in Machining with Large Negative Rake Angle as Basis for Understanding of Grinding," Journal of Materials Processing Technology, Volume 234, pp. 58-71, 2016.

[10] Akbar, F., Mativenga, P. T., and Sheikh, M. A., "An Evaluation of Heat Partition Models in High Speed Machining of AISI/SAE 4140 Steel," in Proceedings of the 6th International Conference on Manufacturing Research (ICMR2008), pp. 13-22, 2008.
[11] Totis, G., Adams, O., Sortino, M., Veselovac, D., and Klocke, F., "Development of an Innovative Plate Dynamometer for Advanced Milling and Drilling Applications," Measurement, Volume 49, pp. 164-181, 2014.

[12] Totis, G. and Sortino, M., "Development of a Modular Dynamometer for Triaxial Cutting Force Measurement in Turning," International Journal of Machine Tools and Manufacture, Volume 51, No. 1, pp. 34-42, 2011.

[13] Yald?z, S. and Ünsaçar, F., "A Dynamometer Design for Measurement the Cutting Forces on Turning," Measurement, Volume 39, No. 1, pp. 80-89, 2006.

[14] Korkut, I., "A Dynamometer Design and Its Construction for Milling Operation," Materials \& design, Volume 24, No. 8, pp. 631-637, 2003.

[15] ?eker, U., Kurt, A., and Ciftci, I., "Design and Construction of a Dynamometer for Measurement of Cutting Forces during Machining with Linear Motion," Materials \& design, Volume 23, No. 4, pp. 355-360, 2002.

[16] Yald?z, S. and Ünsaçar, F., "Design, Development and Testing of a Turning Dynamometer for Cutting Force Measurement," Materials \& design, Volume 27, No. 10, pp. 839-846, 2006.

[17] Yald?z, S., Ünsaçar, F., Sa?lam, H., and I??k, H., "Design, Development and Testing of a Four-Component Milling Dynamometer for the Measurement of Cutting Force and Torque," Mechanical Systems and Signal Processing, Volume 21, No. 3, pp. 1499-1511, 2007.

[18] Karabay, S., "Analysis of Drill Dynamometer with Octagonal Ring Type Transducers for Monitoring of Cutting Forces in Drilling and Allied Process," Materials \& design, Volume 28, No. 2, pp. 673-685, 2007.

[19] Oraby, S. E. and Hayhurst, D. R., "High-Capacity Compact Three-Component Cutting Force Dynamometer," International Journal of Machine Tools and Manufacture, Volume 30, No. 4, pp. 549-559, 1990. 
[20] Xu, D., Feng, P., Li, W., Ma, Y., and Liu, B., "Research on Chip Formation Parameters of Aluminum Alloy 6061-T6 Based on High-Speed Orthogonal Cutting Model," International Journal of Advanced Manufacturing Technology, Volume 72, No. 5-8, pp. 955-962, 2014.

[21] Sima, M. and Özel, T., "Modified Material Constitutive Models for Serrated Chip Formation Simulations and Experimental Validation in Machining of Titanium Alloy Ti-6Al-4V," International Journal of Machine Tools and Manufacture, Volume 50, No. 11, pp. 943-960, 2010.

[22] Rizal, M., Ghani, J. A., Zaki, M., Hassan, C., and Haron, C., "Development and Testing of an Integrated Rotating Dynamometer on Tool Holder for Milling Process," Mechanical Systems and Signal Processing, Volume 52, pp. 559-576, 2015.

[23] Byrne, G., Dornfeld, D., Inasaki, I., Ketteler, G., König, W., and Teti, R., "Tool Condition Monitoring (TCM)the Status of Research and Industrial Application," CIRP Annals-Manufacturing Technology, Volume 44, No. 2, pp. 541-567, 1995.

[24] ABAQUS, "ABAQUS 6.11 Document," 돈 Dassault Systemes, Volume IV, 2011.

[25] Lesuer, D. R., Kay, G. J., and LeBlanc, M. M., "Modeling Large Strain, High Rate Deformation in Metals," Third Biennial Tri-Laboratory Engineering Conference Modeling and Simulation, pp. 3-5, 2001.

[26] Johnson, G. R. and Cook, W. H., "A Constitutive Model and Data for Metals Subjected to Large Strains, High Strain Rates and High Temperatures," 7th International Symposium on Ballistics. pp. 541-547, 1983.

[27] Johnson, G. R. and Cook, W. a, "Fracture Characteristic of Three Metals Subjected to Various Strains, Strain Rates, Temperatures and Pressures," Engineering Fracture Mechanics, Volume 21, No. 1, pp. 31-48, 1985.
[28] Rosakis, P., Rosakis, A. J., Ravichandran, G., and Hodowany, J., "Thermodynamic Internal Variable Model for the Partition of Plastic Work into Heat and Stored Energy in Metals," Journal of the Mechanics and Physics of Solids, Volume 48, No. 3, pp. 581-607, 2000.

[29] Villumsen, M. F. and Fauerholdt, T. G., "Prediction of Cutting Forces in Metal Cutting, Using the Finite Element Method, a Lagrangian Approach," in Proceedings of the 7th German LS-DYNA Forum, Volume 8, 2008.

[30] Daoud, M., Chatelain, J.-F., and Bouzid, H., "On the Effect of Johnson Cook Material Constants to Simulate A12024-T3 Machining Using Finite Element Modeling," in ASME 2014 International Mechanical Engineering Congress and Exposition, 2014, pp. 1987-1997.

[31] Krishnakumar, P., Marimuthu, K. P., Rameshkumar, K., and Ramachandran, K. I., "Finite Element Simulation of Effect of Residual Stresses during Orthogonal Machining Using ALE Approach," International Journal of Machining and Machinability of Materials, Volume 14, No. 3, pp. 213-229, 2013.

[32] Duan, C. Z., Yu, H. Y., Cai, Y. J., and Li, Y. Y., "Finite Element Simulation and Experiment of Chip Formation during High Speed Cutting of Hardened Steel," Applied Mechanics and Materials, Volume 29-32, No. 5, pp. 1838-1843, 2010.

[33] Mabrouki, T. and Rigal, J. F., "A Contribution to a Qualitative Understanding of Thermo-Mechanical Effects during Chip Formation in Hard Turning," Journal of Materials Processing Technology, Volume 176, No. 1-3, pp. 214-221, 2006.

[34] Sungra, G. H., Malik, A. Q., and Sanaullah, K., "The Waveshaper Effect on Ta-MS Multiliner Explosive Formed Pojectile with Tantalum as Penetrator and Mild Steel as Stabilization Base," Mehran University Research Journal of Engineering and Technology, Volume 30, No. 3, pp. 417-426, 2011. 
[35] Akbar, F., Mativenga, P. T., and Sheikh, M. A., "An Experimental and Coupled Thermo-Mechanical Finite Element Study of Heat Partition Effects in Machining," International Journal of Advanced Manufacturing Technology, Volume 46, No. 5-8, pp. 491-507, 2010.

[36] Umbrello, D., Davies, M., Jawahir, I. S., and Arrazola, P. J., "CIRP Annals - Manufacturing Technology Recent Advances in Modelling of Metal Machining Processes," Volume 62, pp. 695-718, 2013.

Umbrello, D., "Finite Element Simulation of Conventional and High Speed Machining of Ti6Al4V Alloy," Journal of Materials Processing Technology, Volume 196, No. 1-3, pp. 79-87, 2008.

Daoud, M., Chatelain, J. F., and Bouzid, A., "Effect of Rake Angle-Based Johnson-Cook Material Constants on the Prediction of Residual Stresses and Temperatures Induced during A12024-T3 Machining Process," International Journal of Mechanical Sciences, Volume 122, No. March 2016, pp. 392-404, 2017.

[39] Wang, B. and Liu, Z., "Simulation Modelling Practice and Theory Shear Localization Sensitivity Analysis for Johnson - Cook Constitutive Parameters on Serrated Chips in High Speed Machining of Ti6A14V," Simulation Modelling Practice and Theory, Volume 55, pp. 63-76, 2015 .

[40] Schwer, L. E., "Aluminum Plate Perforation?: A Comparative Case Study Using Lagrange with Erosion , Multi-Material ALE, and Smooth Particle Hydrodynamics," 7th European LS-DYNA Conference, p. $28,2009$.

[41] Jaffery, S. H. I., Khan, M., Ali, L., and Mativenga, P. T., "Statistical Analysis of Process Parameters in Micromachining of Ti-6Al-4V Alloy," Proceedings of the Institution of Mechanical Engineers, Part B: Journal of Engineering Manufacture, Volume 230, No. 6, pp. 1017-1034, Jan. 2015.
[42] Warsi, S. S., Jaffery, S. H. I., Ahmad, R., Khan, M., Agha, M. H., and Ali, L., "Development and Analysis of Energy Consumption Map for High Speed Machining of Al 6061T6 Alloy," International Journal of Advanced Manufacturing Technology, Volume 96, pp. 91-102, 2018 .

[43] Systèmes, D., "Abaqus Analysis User's Guide," Dassault Systèmes Simulia Corp., Proidence, RI, USA, 2014.

[44] Lesuer, D. R., Kay, G. J., and LeBlanc, M. M., "Modeling Large Strain, High Rate Deformation in Metals," Lawrence Livermore National Lab., CA (US), 2001.

[45] Atlati, S., Moufki, A., Nouari, M., and Haddag, B., "Crossmark," Tribiology International, Volume 105, No. May 2016, pp. 326-333, 2017.

[46] Saptaji, K. and Subbiah, S., "Finite Element Study of the Effect of Substrate Properties in Micro-Cutting Thin Workpiece Materials," in IOP Conference Series: Materials Science and Engineering, 2016, Volume 114, No. 1, p. 12005.

[47] Bourne, K. A., Kapoor, S. G., and DeVor, R. E., "Study of the Mechanics of the Micro-Groove Cutting Process," in Proceedings of the ASME 2011 International Manufacturing Science and Engineering Conference, Paper No. MSEC2011-50076, 2011.

[48] Balbaa, M. A. and Nasr, M. N. A., "Prediction of Residual Stresses after Laser-Assisted Machining of Inconel 718 Using SPH," Procedia CIRP, Volume 31, pp. 19-23, 2015.

[49] Fratini, L., Macaluso, G., and Pasta, S., "Journal of Materials Processing Technology Residual Stresses and FCP Prediction in FSW through a Continuous FE Model," Volume 209, pp. 5465-5474, 2009.

[50] Ar?soy, Y. M. and Özel, T., "Prediction of Machining Induced Microstructure in Ti-6Al-4V Alloy Using 3-D FE-Based Simulations: Effects of Tool Micro-Geometry, Coating and Cutting Conditions," Journal of Materials Processing Technology, Volume 220, pp. 1-26, 2015. 
[51] Nouari, M., List, G., Girot, F., and Ge, D., "Effect of Machining Parameters and Coating on Wear Mechanisms in Dry Drilling of Aluminium Alloys," Volume 45, pp. 1436-1442, 2005.

[52] Gorana, V. K., Jain, V. K., and Lal, G. K., "Forces Prediction during Material Deformation in Abrasive Flow Machining," Wear, Volume 260, pp. 128-139, 2006.
[53] Salguero, J., Batista, M., Calamaz, M., Girot, F., and Marcos, M., "Cutting Forces Parametric Model for the Dry High Speed Contour Milling of Aerospace Aluminium Alloys," Procedia Engineering, Volume 63, pp. 735-742, 2013.

[54] Prasad, C. S., "Finite Element Modeling to Verify Residual Stress in Orthogonal Machining," Dissertation, 2009. 